ISSN: 2224-0616

Int. J . Agril. Res. Innov. \& Tech. 3 (2): 54-58, December, 2013 Available online at http://www.ijarit.webs.com

\title{
AGED LEAVES EFFECT ON ESSENTIAL COMPONENTS IN GREEN AND OOLONG TEA
}

\author{
M.M. Rahman1*, M.A. Kalam', M.A. Salam² and M.R. Rana1
}

Received 20 September 2013, Revised 28 November 2013, Accepted 25 December 2013, Published online 31 December 2013

\begin{abstract}
Tea leaf encompasses essential components like caffeine, polyphenol, lipid etc. The study was conducted to find out the essential constituents in green and oolong tea from aged tea leaves during the year of 2012. Tea leaves with different plucked aged were collected from Lackatoorah Tea Estate at sylhet district in Bangladesh. Collected leaves were processesed to make desirable samples for biochemical analysis in the laboratory of Department of Food Enginnering and Tea Technology, SUST. Results revealed that the essential constituents like moisture, caffeine, polyphenol, lipid, protein, ash, ascorbic acid, acidity and $\mathrm{pH}$ value in green tea made from different aged leaves were found slightly higher than oolong tea, ranged from $6.38 \pm 1.06$ to $3.49 \pm 0.59 \% ; 4.91 \pm 0.82$ to $1.49 \pm 0.24 \% ; 30.88 \pm 5.15$ to $18.23 \pm 3.04 \%$; $7.50 \pm 1.25$ to $9.58 \pm 1.59 \% ; 13.15 \pm 2.19$ to $17.33 \pm 2.88 \% ; 3.87 \pm 1.65$ to $7.86 \pm 1.31 \% ; 48.4 \pm 8.05$ to $21.3 \pm 3.55$ (mg); $2.13 \pm 0.68$ to $1.18 \pm 0.19 \%$ and $5.52 \pm 0.11$ to $5.97 \pm 0.18 \%$, respectively. Similarly, the moisture, caffeine, polyphenol, lipid, protein, ash, ascorbic acid, acidity and $\mathrm{pH}$ value from different aged leaves were found in oolong tea from $6.19 \pm 1.04$ to $2.98 \pm 0.49 \% ; 4.68 \pm 0.78$ to $1.11 \pm 0.19 \% ; 20.89 \pm 3.48$ to $8.23 \pm 1.37 \%$; $6.40 \pm 1.07$ to $9.13 \pm 1.52 \% ; 13.03 \pm 2.17$ to $17.19 \pm 2.86 \% ; 3.44 \pm 0.58$ to $7.57 \pm 1.27 \% 6.44 \pm 1.08$ to $0.98 \pm 0.17$ (mg); $2.02 \pm 0.34$ to $1.02 \pm 0.17 \%$ and $5.53 \pm 0.11$ to $5.97 \pm 0.20 \%$, respectively. Therefore, young tea leaves (i.e. 5 to 8 days tea leaves) should be plucked for considering useful constituents in processed green tea and oolong tea.
\end{abstract}

Keywords: Tea Leaves, Components, UV-Spectrophotometer, Green Tea, Oolong Tea

${ }^{1}$ Department of Food Engineering and Tea Technology, Shahjalal University of Science and Technology, Sylhet-3114, Bangladesh ${ }^{2}$ Department of Chemical Engineering and Polymer Science, Shahjalal University of Science and Technology, Sylhet-3114, Bangladesh

*Corresponding author's email: bau_mintu@yahoo.com (M.M. Rahman)

\section{Introduction}

Tea (Camellia sinensis L.) is the oldest and cheapest health beverage in the world next to water which is mostly grown in the sub-tropical regions in Asia and occupies about 2.7 million hectares of cultivable area in the world (Chaudhury, 1989; Mandel and Youdim, 2004). In presence, there are almost 30 countries producing $70 \%$ black tea, $25 \%$ green tea and the remaining $5 \%$ consisted of oolong tea (FAO, 2010). Like black tea, green and oolong tea are widely made in Asian countries to consume as a beverage and has been familiar in China and Japan from centuries (Zaveri, 2006). Green tea, called non-fermented tea has a more subtle, delicate flavour, and far less caffeine than fermented tea, is medicinally beneficial because the non-fermented leaves retain a higher concentration of natural vitamins and polyphenols than fermented counterparts. Oolong tea is a semi-fermented tea especially good for digestion, is advised to take after a large meal. The chemical compositions counted in semi-fermented oolong tea are in the ranges of non-fermented green tea to fully fermented black tea. The optimal matured tea leaves are plucked for processing into green and oolong tea at an interval in order to maintain better quality and essential constituents in tea.

The chemical constituents in green and oolong tea differ due to plucking of different days tea leaves and leaves processing system. Better plucked leaves provide desirable nutrient profiles like caffeine, polyphenol, lipid, protein etc., that are responsible for maintaining better human health. The chemical composition in tea deals with the changes of biochemical occurs during the seed germination, growth of the plants, manufacturing of tea and ends up with the pharmaceutical uses for drinking tea as a beverage (Choudhury, 2010). Tea caffeine is a crucial factor contains 1 to $5 \%$ of its dry weight (Amra et al., 2006) depending on types, brand (Bennett and Bonnie, 2001) and brewing method (Hicks et al., 1996). Tea leaves belong polyphenol group figured out for 25 to 35\% on a dry weight basis (Balentine, 1997; Hara et al., 1995). Anesini et al. (2008) reported the total ployphenol content in green tea that varies from $14.32 \pm 0.45$ 
to $21.02 \pm 1.54 \%$. The value of lipid content in tea differs due to the variety and climatic condition. Lipid presents in tea up to 7-10 percent by weight may or not have any significant role on the quality in the manufacturing process (TRIC, 1948). Green tea leaves on dry weight basis contains $15-20 \%$ protein (Cabrera et al., 2006) whereas crude protein (CP) is counted $18.15 \%$ (on the dry air basis) in the tested green tea leaves. The moisture content is a vital factor, which should be 3 to 7 percent in processed tea (Harler, 1964). The mean moisture content in all tea samples was $6.8 \%$, ranged from $5.6-7.5 \%$ with Mambila and Srilanka tea having the lowest contents of 5.6 and $6.5 \%$, respectively (Mohammed and Suliman, 2009). The ash content analysis has ranged from $4.9 \%-7.2 \%$ in Kenya and Mambila samples contained the high ash content of $7.2 \%$ while Srilanka had the lowest of $4.9 \%$. This high ash content suggests that it is a good source of minerals. Ascorbic acid is greater in the younger shoots than mature tea leaves but lesser in shaded shoots in comparison with that of un-shaded ones. Black and oolong teas have lesser amount of ascorbic acid than green tea (Takayanagi, 1977). $\mathrm{pH}$ is the most responsible factor for the production of pigmented compounds- theaflavins and thearubigins having specific optimum $\mathrm{pH}$ at 5.0 and 6.0 respectively (Nestle, 1966). Choudhury (2001) reported that green tea leaves having a $\mathrm{pH}$ value of 5.06-5.80, moisture content $78-80$ and $20-25$ percents of dry matter content respectively.

The quality of tea depends on leaf processing and manufacturing methods. Tea component may vary in the different aged plucked tea leaves. Normally according to the leaf plucking cycle, leaves are plucked after an interval to retain essential nutrient profiles in made tea. In the tea growing developing countries like Bangladesh does not follow up this properly due to labor shortages and for this reason leaf gets more time to become mature and provides poor nutrient contents in processed tea. As there is no absolute measurement, yet how nutrient profile changes in oolong and green tea from aged tea leaves. In view of the above discussions, the experiment has been carried out to analyze the effect of aged tea leaves on essential components in green and oolong tea in Bangladesh.

\section{Materials and Methods}

\section{Samples collection and preparation}

The different aged tea leaves (Camellia sinensis) were collected from Lackatoorah Tea Estate, Sylhet, Bangladesh to analyze the biochemical compounds in the Department of Food Engineering and Tea Technology, Shahjalal University of Science and Technology (SUST), Sylhet, Bangladesh during the period of MayJ uly, 2012. Tea leaves were divided into two parts in order for producing the green tea and oolong tea. The processing system of green tea and oolong tea were outlined below:

\section{a) Manufacturing process of green tea}

Different aged plucked tea leaves were manually steamed to retain greenish colour for 45-60 second and then dried in sunlight, when leaves were fully dried, crushed or grinded to make a powder form for further analysis in the lab. Then each sample was preserved separately in a small plastic pot with the air tight condition to protect this from micro-organisms. As it is processed without fermentation, the sample colour was almost green; no typical aroma was developed and liquor has not trace of red or brown coloration.

\section{b) Manufacturing process of oolong tea}

After plucking, aged tea leaves were spread thinly on the flat bamboo basket for withering under direct sun for 30-60 minutes. The withering process time varies depending on the availability of sunlight. After then, tea leaves were transferred to a floor with the shady condition for further withering for 6-8 hours and agitated by hand one hour interval. In this process, the border of tea leaves became red and a strong aroma evaporates with the decreasing of moisture content gradually. The withered leaves were then dried to inactivate the enzymes for fermentation. The partially dried leaves were crushed and re-dried under sunlight to receive oolong tea having moisture content below 7 percent and stored in an air-tight plastic pot for further biochemical analysis.

\section{Determination of essential components in green and oolong tea}

Moisture content for each tea sample was determined using an oven set at $102^{\circ} \mathrm{C}$ and dried to constant weight (AOAC, 1984). The caffeine was determined by separating from the sample by refluxed and filtered. The filtered is then extracted with chloroform as solvent which removed by evaporation and weigh the caffeine (AACC, 2000). The total polyphenol content (TPC) was determined by spectrophotometer (T60UV-Spectrophotometer) using Gallic acid as standard, according to the method described by the International Organization for Standardization (ISO, 2005). Lipid content in the samples was determined using soxhlet extraction method (AOAC, 2000). Protein content was analyzed using Kjeldhal digestion method followed by distillation and titration (AOAC, 2000). Total ash was determined using Muffle furnace set at $550^{\circ} \mathrm{C}$ for $3 \mathrm{hrs}$ (AACC, 2000). $\mathrm{pH}$ of the tea infusion was determined by using portable $\mathrm{pH}$ meter according to method AOAC (1990). The amount of ascorbic acid was measured by preparing iodine solution and then titrating. Total acidity of made tea sample was determined by titrating samples against $0.1 \mathrm{~N}$ 
sodium hydroxide solution to persistent pink color following protocols of AOAC (1990).

\section{Results and Discussion}

\section{Aged tea leaves effect on essential components in green tea and oolong tea}

Results revealed the effect of aged tea leaves on essential components in green and oolong tea, which are presented in Table 1 and Table 2. The values of moisture content decreased gradually from 5 to 12 days tea leaves (i.e., young to mature leaves) which had in the range of $6.38 \pm 1.06$ to $3.49 \pm 0.59 \%$ at green tea and $6.19 \pm 1.04$ to $2.98 \pm 0.49 \%$ at oolong tea, is similar with the finding of Harler (1964). The variation in the moisture may be attributed to the degree of drying type and nature of tea involved (Kumar et al., 2005).

The caffeine content in green and oolong tea samples analyzed varied from $4.91 \pm 0.82$ to $1.49 \pm 0.24 \%$ and $4.68 \pm 0.78$ to $1.11 \pm 0.19 \%$ at 5 days to 12 days tea leaves, which is similar with the reporting of Amra et al. (2006) who found 1 to $5 \%$ of its dry weight caffeine contain in various tea. The result of polyphenol content in Table 1 showed that green tea from 5-12 days tea leaves had the highest polyphenol content of $30.88 \pm 5.15 \%$ and $18.23 \pm 3.04 \%$ while oolong tea was the lowest of $20.89 \pm 3.48 \%$ and $8.23 \pm 1.37 \%$ in Table 2, is compared with the finding of Anesini et al. (2008) and Balentine et al. (1997). Polyphenol content is always lower in the first leaf harvested after pruning than that of subsequent flushes and applicable for tea grown under shade (Eden, 1960).

The values of lipid content were gradually increased in green and oolong tea from 5-12 days tea leaves which ranged from $7.50 \pm 1.25$ to $9.58 \pm 1.59 \%$ and $6.40 \pm 1.07$ to $9.13 \pm 1.52 \%$, which is significant with the result of Hara et al. (1995) found $7-10 \%$ lipid in various tea. Protein contents from 5-12 days tea samples are below as shown in Table 1 and 2, range of $13.15 \pm 2.19$ to $17.33 \pm 2.88 \%$ in green tea and $13.03 \pm 2.17$ to $17.19 \pm 2.86 \%$ in oolong tea, which is within the acceptable range of Cabrera et al. (2006). The ash content in tea is an indication of its mineral content; it does not necessarily indicate high quality except when there is a favorable balance of the essential minerals (Ahmed et al., 1989). The results of the ash content analysis in green tea at 5-12 days tea leaves are outlined in Table 1 with ranged from $3.87 \pm 1.65$ to $7.86 \pm 1.31 \%$ and in 0olong tea from $3.44 \pm 0.58$ to $7.57 \pm 1.27 \%$ in Table 2 . These results were within the limit recommend for tea sample (Ahmed et al., 1989).

Table 1 Aged leaves effects on essential components in green tea*

\begin{tabular}{|c|c|c|c|c|c|c|c|c|c|}
\hline \multirow{2}{*}{$\begin{array}{c}\text { Sample } \\
\text { Types }\end{array}$} & \multicolumn{9}{|c|}{ Essential components in green tea } \\
\hline & Moisture\% & Caffeine $\%$ & Polyphenol\% & Lipid\% & Protein\% & Ash\% & $\begin{array}{l}\text { Ascorbic } \\
\text { Acid, mg }\end{array}$ & Acidity\% & $\overline{\mathrm{PH}} \%$ \\
\hline 5 days & $6.38 \pm 1.06$ & $4.91 \pm 0.82$ & $30.88 \pm 5.15$ & $7.50 \pm 1.25$ & $13.15+2.19$ & $3.87 \pm 1.65$ & $48.4 \pm 8.05$ & $2.13 \pm 0.68$ & $5.52 \pm 0.11$ \\
\hline 6 days & $5.98 \pm 0.82$ & $4.22 \pm 0.70$ & $28.08 \pm 4.68$ & $7.95 \pm 1.33$ & $13.65 \pm 2.29$ & $4.54 \pm 0.76$ & $41.7 \pm 6.95$ & $2.01 \pm 0.34$ & $5.55 \pm 0.12$ \\
\hline 7 days & $5.23 . \pm 0.88$ & $3.82 \pm 0.63$ & $27.79 \pm 4.63$ & $8.21 \pm 1.36$ & $14.37 \pm 2.39$ & 5.11. \pm 0.86 & $34.7 \pm 5.75$ & $1.87 \pm 0.32$ & $5.61 \pm 0.21$ \\
\hline 8 days & $4.89 \pm 0.82$ & $3.34 \pm 0.55$ & $26.02 \pm 4.33$ & $8.75 \pm 1.45$ & $15.05 \pm 2.50$ & $5.58 \pm 0.93$ & $32.6 \pm 5.45$ & $1.82 \pm 0.30$ & $5.72 \pm 0.23$ \\
\hline 9 days & $4.47 \pm 0.75$ & $2.83 \pm 0.47$ & $24.11 \pm 4.02$ & $8.99 \pm 1.22$ & $15.34 \pm 2.55$ & $6.02 \pm 1.00$ & $30.2 \pm 5.05$ & $1.67 \pm 0.28$ & $5.78 \pm 0.09$ \\
\hline 10 days & $4.14 \pm 0.56$ & $2.34 \pm 0.39$ & $22.50 \pm 3.75$ & $9.11 \pm 1.52$ & $15.77 \pm 2.62$ & $6.43 \pm 1.08$ & $27.7 \pm 4.65$ & $1.53 \pm 0.26$ & $5.86 \pm 0.14$ \\
\hline 11 days & $3.82 \pm 0.64$ & $1.88 \pm 0.31$ & $20.44 \pm 3.40$ & $9.34 \pm 1.56$ & $16.23 \pm 2.70$ & $7.14 \pm 1.19$ & $25.6 \pm 4.25$ & $1.38 \pm 0.23$ & $5.92 \pm 0.25$ \\
\hline 12 days & $3.49 \pm 0.59$ & $1.49 \pm 0.24$ & $18.23 \pm 3.04$ & $9.58 \pm 1.59$ & $17.33 \pm 2.88$ & $7.86 \pm 1.31$ & $21.3 \pm 3.55$ & $1.18 \pm 0.19$ & $5.97 \pm 0.18$ \\
\hline
\end{tabular}

*The values indicates Mean \pm Standard Deviation

Table 2. Aged leaves effects on essential components in oolong tea*

\begin{tabular}{|c|c|c|c|c|c|c|c|c|c|}
\hline \multirow{2}{*}{$\begin{array}{l}\text { Sample } \\
\text { Types }\end{array}$} & \multicolumn{9}{|c|}{ Essential components in oolong tea } \\
\hline & Moisture\% & Caffeine\% & Polyphenol\% & $\underset{\%}{\text { Lipid }}$ & $\begin{array}{c}\text { Protein } \\
\%\end{array}$ & Ash\% & $\begin{array}{l}\text { Ascorbic } \\
\text { acid, mg }\end{array}$ & $\begin{array}{c}\text { Acidity } \\
\%\end{array}$ & $\mathrm{PH} \%$ \\
\hline 5 days & $6.19 \pm 1.04$ & $4.68 \pm 0.78$ & $20.89 \pm 3.48$ & $6.40 \pm 1.07$ & $13.03 \pm 2.17$ & $3.44 \pm 0.58$ & $6.44 \pm 1.08$ & $2.02 \pm 0.34$ & $5.53 \pm 0.11$ \\
\hline 6 days & $5.97 \pm 0.99$ & $3.92 \pm 0.65$ & $19.26 \pm 3.21$ & $6.85 \pm 1.15$ & $13.54 \pm 2.25$ & $3.86 \pm 0.65$ & $5.09 \pm 0.85$ & $1.91 \pm 0.31$ & $5.50 \pm 0.12$ \\
\hline 7 days & 5.07. \pm 0.85 & $3.35 \pm 0.55$ & $18.08 \pm 3.01$ & $7.23 \pm 1.20$ & $12.24 . \pm 2.35$ & 4.53. \pm 0.76 & $4.76 \pm 0.79$ & $1.78 \pm 0.29$ & $5.60 \pm 0.11$ \\
\hline 8 days & $4.39 \pm 0.74$ & $2.93 \pm 0.48$ & $17.05 \pm 2.84$ & $7.52 \pm 1.26$ & $14.97 \pm 2.49$ & $5.09 \pm 0.82$ & $4.31 \pm 0.72$ & $1.65 \pm 0.28$ & $5.62 \pm 0.13$ \\
\hline 9 days & $3.98 \pm 0.66$ & $2.43 \pm 0.40$ & $14.55 \pm 2.43$ & $7.92 \pm 1.32$ & $15.17 \pm 2.52$ & $5.83 \pm 0.98$ & $3.86 \pm 0.65$ & $1.43 \pm 0.24$ & $5.76 \pm 0.19$ \\
\hline 10 days & $3.53 \pm 0.59$ & $1.99 \pm 0.34$ & $12.79 \pm 2.13$ & $8.31 \pm 1.38$ & $15.65 \pm 2.60$ & $6.22 \pm 1.04$ & $2.34 \pm 0.40$ & $1.27 \pm 0.22$ & $5.83 \pm 0.15$ \\
\hline 11 days & $3.14 \pm 0.53$ & $1.48 \pm 0.25$ & $9.70 \pm 1.61$ & $8.86 \pm 1.47$ & $16.13 \pm 2.68$ & $7.05 \pm 1.18$ & $1.32 \pm 0.22$ & $1.13 \pm 0.18$ & $5.93 \pm 0.17$ \\
\hline 12 days & $2.98 \pm 0.49$ & $1.11 \pm 0.19$ & $8.23 \pm 1.37$ & $9.13 \pm 1.52$ & $17.19 \pm 2.86$ & $7.57 \pm 1.27$ & $0.98 \pm 0.17$ & $1.02 \pm 0.17$ & $5.97 \pm 0.20$ \\
\hline
\end{tabular}

*The values indicates Mean \pm Standard Deviation 
The ascorbic acid in green tea from 5-12 days tea leaves was found $48.4 \pm 8.05$ to $21.3 \pm 3.55 \mathrm{mg}$ while oolong tea was $6.44 \pm 1.08$ to $0.98 \pm 0.17$ (mg) in Table 2. Nagao et al. (2005) reported that green tea leaves contained $17.5 \mathrm{mg} \mathrm{kg}^{1}$ ascorbic acid. The content of acidity in green and oolong tea samples manufactured from 5-12 days tea leaves ranged from $2.13 \pm 0.68$ to $1.18 \pm 0.19 \%$ and $2.02 \pm 0.34$ to $1.02 \pm 0.17 \%$, respectively. The ranges of $\mathrm{pH}$ content in green tea at 5-12 days tea leaves were $5.52 \pm 0.11$ to $5.97 \pm 0.18 \%$ while oolong tea had $5.53 \pm 0.11$ to $5.97 \pm 0.20 \%$, which is similar result of Choudhury (2001) that green tea leaves having $\mathrm{pH}$ value of $5.06-5.80 \%$. Brunton and Hussain (2001) reported that both conventional oolong tea and herbal tea eroded dental enamel. They also stated that the $\mathrm{pH}$ of conventional oolong and herbal tea had been measured to be lower than the critical $\mathrm{pH}$ (5.5) that is necessary for the demineralization of enamel. According to their results, the erosive effect of herbal tea was found to be five times greater than that of conventional oolong tea.

\section{Conclusion}

Normally tea is collected from tea garden with maintaining proper plucking cycle retained the optimum quality in processed tea, but after over plucking, tea can get more time to make mature and show lower nutrient values like caffeine and polyphenol content in made green tea and oolong tea. The study revealed that the useful compositions found in green and oolong tea are acceptable in young tea leaves (i.e. 5 to 8 days) than mature ones (i.e.9 days to others). Based on the findings can be recommended leaf plucked from tea estate within 5 days to 8 days to maintain excellent quality in processed tea.

\section{References}

AACC. 2000. The determination of crude fibre in food. Standard using the Fibrecap 2021/2023.

Ahmed, I., Zaidi, S.S.H. and Khan, Z.A. 1989. The determination of major, minor and trace elements in tea, tea liquor, instant coffee and cocoa samples. Pakistan J. Sci. Ind. Res. 32 (8): 513-515.

Amra, P., Mojca, S., Zeljko, K., Bernd, W., Frank, O. and Sabine, G. 2006. Extraction of active ingredients from green tea (Camellia sinensis); Extraction efficiency of major catechins and caffeine. Food Chem. 96: 597605.

Anesini, C., Ferraro, G.E. and Filip, R. 2008. Total polyphenol content and antioxidant capacity of commercially available tea (Camellia sinensis) in Argentina. J. Agric. Food Chem. 56: 9225- 9229.
AOAC. 1984. Official Methods of Analysis of the Association of Analytical Chemists. 14th edn. Washington DC,USA.

AOAC. 1990. Official Methods of Analysisof the Association of Analytical Chemists. 15th edn. Washinton DC, USA

AOAC. 2000. Official Methods of Analysis of the Association of Analytical Chemists. 17th edn. Washinton DC, USA.

Bennett, A.W. and Bonnie, K.B. 2001. The world of caffeine: The science and culture of the World's Most Popular Drug. Rutledge. p. 228.

Brunton, P.A. and Hussain, A. 2001. The erosive effect of herbal tea on dental enamel. J. Dentistry. 29: 517-520.

Cabrera, C., Artacho, R. and Giménez, R. 2006. Beneficial effects of green tea: a review. J. American College Nutr. 25: 79-99.

Chaudhury, M.S.H. 1989. Tea Growing. 1st Ed. Ananda printer 166. Arambagh. Motijheel. Dhaka-1000. pp. 101-125.

Choudhury, M.A. 2001. Optimum Fermenting Factors in the formation of Theaflavins from Crude Catechin in vitro Model System and their Significance in storing. International Conference on O-Cha (tea) Culture and Science. Shizuoka. Japan. pp. 29-59.

Choudhury, M.A. 2010. Optimum quality teas processing and pharmaceutical uses. $1^{\text {st }}$ Ed. S. Ahmed Computer, Srimangal. pp.53-55.

Eden, T. 1960. The development of tea culture. In: Tea. Ed. Eden. Longman, London. pp. 14.

FAO. 2010. Committee on commodity problems, intergovernmental group on tea, Market development and outlook. Retrieved March $16^{\text {th }} 2012$, from http:/ / www.fao.org/ docrep / meeting/ 018/ K7503E.pdf.

Hara, Y.L., Wickremasinghe, S.J . and Yamanishi, R.L. 1995. Special issue on tea. Food Res. Int. 11: 371- 545.

Balentine, D.A. and Harbowy, M.E. 1997. Tea chemistry. Crit. Res. Plant Sci. 16: 415- 481.

Harler, C.R. 1964.The Cuttivation and Marketing of Tea. 3rd edn. Oxford: Oxford University Press, London.

Hicks, M.B., Hsieh, Y.H.P. and Bell, L.N. 1996. Tea preparation and its influence on methylxanthine concentration. Food Res. Int. 29 (3-4): 325- 330.

ISO. 2005. Determination of substances characteristic of green and black tea. Part 1: Content of total polyphenols in tea, Colorimetric method using Folin-Ciocalteu reagent. 14502-1(22).

Kumar, A., Nair, A.G.C., Reddly, A.V.R. and Garg, A.N. 2005. Availability of essential elements in India and US tea brands. Food Chem. 89: 441-448. 
Mandel, S. and Youdim, M.B. 2004. Catechin polyphenols: neurodegeneration and neuroprotection in neurodegenerative diseases. Free Radical Biol. Med. 37 (3): 304- 317.

Mohammed, M.I. and Suliman, M.A. 2009. Proximate, caffeine and tannin analyses in some brands of tea consumed in Kano Metropolis, Nigeria. Bayero J. Pure \& Appl. Sci. 2 (2): $19-21$.

Nagao, T., Komine, Y., Soga, S., Meguro, S., Hase, T., Tannaka, Y. and Tokimitsu, I. 2005. Ingestion of a tea rich in catechins leads to a reduction in body fat and malonaldialdehyde-modified LDL in man. American J . Clinical Nutr. 81: 122-129.

Nestle. 1966. Patent specification, Great Britain. $1,034,670$.

Takayanagi, H. 1977. Relationship between the contents of manganese and vitamin $\mathrm{C}$ in leaves of shaded tea. Study of Tea. $52 \mathrm{p}$.

TRIC, 1948. Tea Research Institute of Ceylon, St. Coombs Estate in Talawakelle, Sri-Lanka. 50 $\mathrm{p}$.

Zaveri, N.T. 2006. Green tea and its polyphenolic catechins: medicinal uses in cancer and noncancer applications. Life Sci. 78: 20732080. 